\title{
Crystallization conditions of lamproitic magmas from Zirkel Mesa (Leucite Hills, USA): data on melting experiments
}

\author{
Eugene I. Petrushin, Lev Sh. Bazarov, Vera I. Gordeeva, Victor V. Sharygin \\ V.S. Sobolev Institute of Geology and Mineralogy, Siberian Branch of Russian Academy of Sciences, \\ Novosibirsk, Russia
}

The experimental study of silicate melt crystallization allows for obtaining the important information on P-T conditions of generation, chemical composition and evolution of melt and has a fundamental importance for the understanding of magmatic processes. The purpose of this paper is obtaining new data on initial crystallization stages of natural orenditic melt. The experimental simulation of minerals crystallization in natural melts allows studying the peculiarities of inclusion trapping during the crystal growth. This investigation was performed on a new heating stage designed by the authors (Petrushin et al. 2003).

\section{Investigated rocks}

Orendite (sanidine-phlogopite-leucite lamproite) from the Zirkel Mesa outcrop, Leucite Hills (Wyoming, USA) was chosen as a starting material for experiments on melting and crystallization. These rocks form volcanic cones and lava flows (Günter et al. 1990) (Fig. 1). Depending on the regime of cooling of primary magmas, lamproites greatly vary in crystallinity, forming varieties from glassy (up to $85 \%$ of glass) up to holocrystalline with similar chemical compositions. The orendite is $\mathrm{SiO}_{2}$-rich (up to 57 wt. \%), has a high content of $\mathrm{K}_{2} \mathrm{O}$ (up to $11 \mathrm{wt}$ \%), and high peralkaline index $\left(\mathrm{K}_{2} \mathrm{O}+\mathrm{Na}_{2} \mathrm{O}\right) / \mathrm{Al}_{2} \mathrm{O}_{3}$ (up to 3). The chemical composition of the investigated rock is given in Table 1. Holocrystalline specimens of orendites without secondary alteration were selected for the experiments. The rocks contain phlogopite phenocrysts (10-15 vol. $\%)$ in the groundmass consisting of leucite (30-35\%), sanidine $(20-30 \%)$, diopside (10-15\%), K- richterite (up to $5 \%$ ), apatite (up to $1.5 \%$ ), priderite $(<1 \%$ ) and interstitial glass (up to 5 vol. \%) (Fig. 2). Xenogenic olivine and late / post- magmatic $\mathrm{Ca}-\mathrm{Ba}-\mathrm{Sr}$-carbonates and barite sometimes occur in the rocks. Phlogopite phenocrysts $(1.5-2 \mathrm{~mm})$ are likely to crystallize at a depth on the early stage of primary magma evolution, while the groundmass has been formed on the surface.

\section{Experimental procedure}

The samples of rock is crushed in a hard alloy stamp, made of tungsten carbide, to prevent sample contamination by silicon or iron. The samples are crushed to powder with a grain of size less than $20 \mu \mathrm{m}$. Further the powder is conditioned in drying chamber at $120-140^{\circ} \mathrm{C}$ for 2 hours to remove moisture.

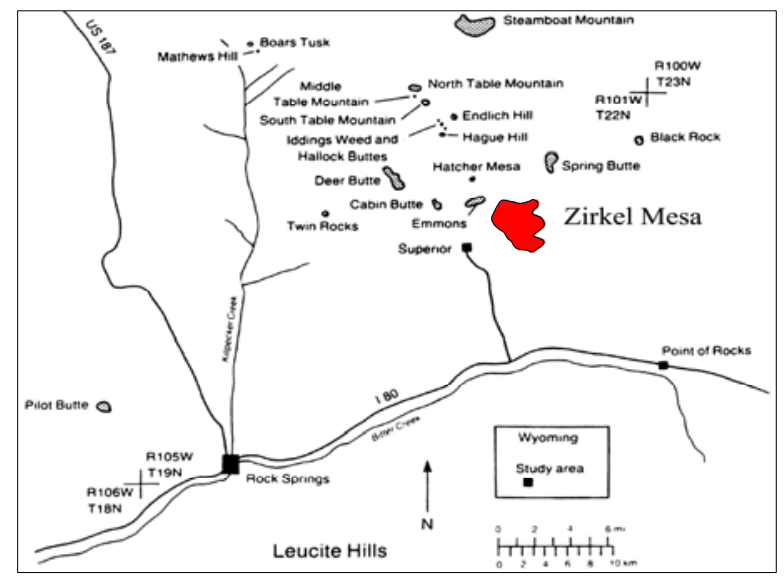

Fig. 1. Location map of Leucite Hills volcanic field (adopted from Günter W.D. et al. 1990).

A charge of mass $0.5-1 \mathrm{~g}$ was placed into a platinum crucible of volume up to $2 \mathrm{~cm}^{3}$. The crucible was placed in a thermal stage. After melting the temperature was raised up to $1350-1400^{\circ} \mathrm{C}$ and withstood during 1.5-2 hours to homogenize the melt. Later the crucible with melt was quenched in the thermal stage, and the obtained glass was used in the subsequent experiments.

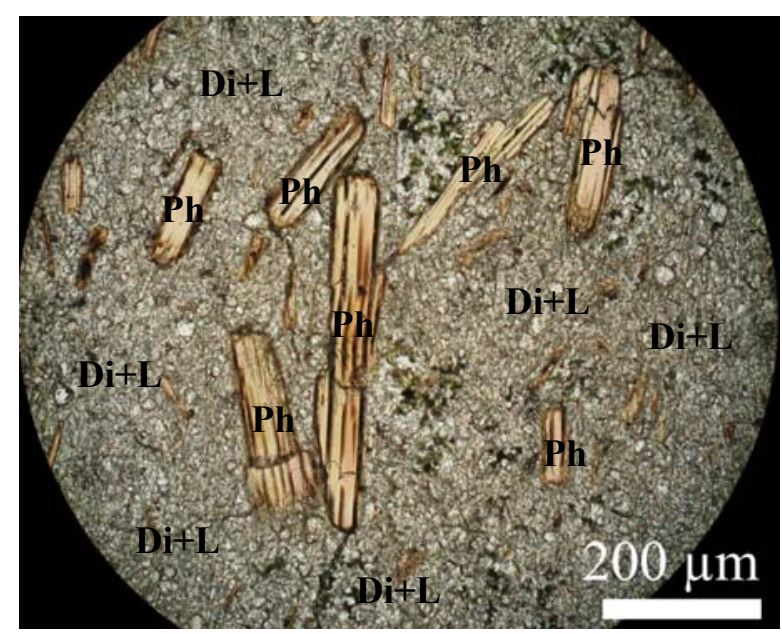

Fig. 2. Orendite, (sanidine - phlogopite - leucite lamproite), consist of phlogopite phenocrysts with groundmass of sanidine, leucite, diopside, K-Ti richterite and glass, are used in our experiments.

Before the experiments, a calibration of thermocouples on points of melting of $\mathrm{Ag}\left(\mathrm{Tm} 960.5^{\circ} \mathrm{C}\right)$ and $\mathrm{Au}(\mathrm{Tm}$ $1063^{\circ} \mathrm{C}$ ) has been made. They have been placed into 
Table 1. Chemical composition of Leucite Hills lamproites investigated experimentally.

\begin{tabular}{|l|l|l|l|l|l|l|l|l|l|l|l|l|l|}
$\mathrm{SiO}_{2}$ & $\mathrm{TiO}_{2}$ & $\mathrm{Al}_{2} \mathrm{O}_{3}$ & $\mathrm{Fe}_{2} \mathrm{O}_{3}$ & $\mathrm{FeO}$ & $\mathrm{MnO}$ & $\mathrm{MgO}$ & $\mathrm{CaO}$ & $\mathrm{BaO}^{-}$ & $\mathrm{Na}_{2} \mathrm{O}$ & $\mathrm{K}_{2} \mathrm{O}$ & $\mathrm{P}_{2} \mathrm{O}_{3}$ & LOI & Total \\
\hline
\end{tabular} \begin{tabular}{l|l|l|l|l|l|l|l|l|l|l|l|l|l|l}
1101 & 48,94 & 1,76 & 12,44 & 4,28 & 3,71 & 0,10 & 5,84 & 4,77 & 0,81 & 2,17 & 11,01 & 0,47 & 2,63 & 98,93 \\
\hline
\end{tabular} \begin{tabular}{|l|l|l|l|l|l|l|l|l|l|l|l|l|l|l|l|l|l|l|}
1102 & 52,64 & 1,72 & 13,38 & 5,19 & 1,63 & 0,09 & 4,40 & 3,16 & 0,37 & 2,22 & 11,96 & 0,44 & 2,50 & 99,70 \\
\hline
\end{tabular} \begin{tabular}{|l|l|l|l|l|l|l|l|l|l|l|l|l|l|l|l|l|}
\hline LH1 & 50,23 & 2,3 & 10,15 & 3,65 & 1,21 & 0,09 & 7,48 & 6,12 & 0,61 & 1,29 & 10,48 & 1,81 & 3,78 & 99,20 \\
\hline
\end{tabular} \begin{tabular}{llllllll|l|l|l|l|l|l|l|l|l|l|l|l|l}
\hline LH7 & 55,43 & 2,64 & 9,13 & 2,12 & 1,48 & 0,08 & 6,11 & 2,69 & 0,64 & 0,94 & 12,66 & 1,52 & 3,14 & 98,58 \\
\hline
\end{tabular} \begin{tabular}{|l|l|l|l|l|l|l|l|l|l|l|l|l|l|l|}
\hline LH10 & 53,07 & 2,41 & 8,96 & 3,86 & 0,91 & 0,08 & 11,17 & 3,56 & 0,34 & 1,15 & 10,72 & 1,24 & 1,32 & 98,79 \\
\hline
\end{tabular} \begin{tabular}{|l|l|l|l|l|l|l|l|l|l|l|l|l|l|l|l|l}
\hline LH12 & 55,14 & 2,58 & 10,35 & 3,27 & 0,62 & 0,06 & 6,41 & 3,43 & 0.52 & 1,21 & 11,77 & 1,40 & 1,63 & 97,87 \\
\hline
\end{tabular}

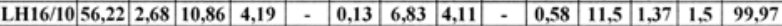

Note. Rocks: 1101 - Massive holocrystalline wyomingite, Emmons Cone; 1102 - Porous, glassy orendite, Emmons Cone [Yagi, Matsumoto 1966]; LH1 - Wyomingite, margin of dyke, Boars Tusk; LH7 Wyomingite, glassy lava, Steamboat Springs; LH10 Olivine-orendite, South Table Mountain; LH12 Orendite, North Table Mountain [Carmichael 1967; Barton, Hamilton 1978, 1982]; LH16/10 - Orendite, Zirkel Mesa [Petrushin et al. 2004].

the micro crucibles made of talc which is annealed at $1200^{\circ} \mathrm{C}$. Temperatures have been controlled with $\mathrm{Pt} /$ PtRh10 thermocouples within $1^{\circ} \mathrm{C}$ of nominal temperature as measured directly under the sample. The liquidus temperature of the samples is determined according to the standard procedure to obtain the equilibrium between crystal-melt that is termed as the approach in two ways. In our case it is made by the commencement of crystallization or leucite melting first crystallizing phase. For this purpose, the orenditic glass is melted and conditioned at $1350-1400^{\circ} \mathrm{C}$ for two hours to reach complete homogenization of the melt. Then the crucible with melt is cooled to the temperature beyond the proposed liquidus and conditioned at the constant temperature for 20-30 $\mathrm{min}$.

Table 2. Results of thermal experiments with Leucite Hills lamproites.

\begin{tabular}{|c|c|c|c|c|c|c|c|}
\hline & 1101 & 1102 & $\mathrm{LH} \mathrm{1}$ & LH 7 & LH 10 & LH 12 & LH16/10 \\
\hline & $1^{\star}$ & $2^{\star}$ & $3^{\star}$ & $4^{\star}$ & $5^{\star}$ & $6^{*}$ & original \\
\hline liquidus & $1322^{\circ} \mathrm{C}$ & $1300^{\circ} \mathrm{C}$ & $1200^{\circ} \mathrm{C}$ & $1165^{\circ} \mathrm{C}$ & $1275^{\circ} \mathrm{C}$ & $1265^{\circ} \mathrm{C}$ & $1300^{\circ} \mathrm{C}$ \\
\hline diopside & $1322^{\circ} \mathrm{C}$ & $1300^{\circ} \mathrm{C}$ & - & - & - & - & - \\
\hline leucite & $1293^{\circ} \mathrm{C}$ & - & $1200^{\circ} \mathrm{C}$ & $1165^{\circ} \mathrm{C}$ & - & $1265^{\circ} \mathrm{C}$ & $1300^{\circ} \mathrm{C}$ \\
\hline olivine & - & - & - & - & $1275^{\circ} \mathrm{C}$ & - & - \\
\hline solidus & $\sim 1000^{\circ} \mathrm{C}$ & - & $\sim 1010^{\circ} \mathrm{C}$ & $\sim 1000^{\circ} \mathrm{C}$ & $1010^{\circ} \mathrm{C}$ & $980^{\circ} \mathrm{C}$ & $\sim 1000^{\circ} \mathrm{C}$ \\
\hline
\end{tabular}

Note: $\left(1^{*}, 2^{*}\right.$ - Yagi, Matsumoto 1966; 3*, 4*, 5* Carmichael 1967; 6*- Barton, Hamilton 1978, 1982, and author's data).

A sample of the melt is taken with the help of platinum sampler and quenched in air for the first seconds. The sample is viewed through a NU-2E microscope $(\times$ 1000 magnification). First samples were homogenous silicate glass only. Then the temperature is lowered to $10^{\circ} \mathrm{C}$, isothermal conditioning is carried out and a melt sample is taken again. This procedure is repeated until first leucite crystals appear. Thereafter the temperature is raised and the difference between isothermal intervals is reduced and we try to reach equilibrium temperature. To improve the liquidus temperature, the procedure is repeated more than once and in this manner we succeed to obtain the values of $1300 \pm$ $10^{\circ} \mathrm{C}$. The interval of the obtained temperature is related to the temperature gradient in a crucible with melt. This gradient is reduced through convection.
Table 3. A comparison of the thermal experiments results - 1 with the melt inclusions data -2 . Spec. 1101.

\begin{tabular}{|c|c|c|c|}
\hline & 1 & 1 & 2 \\
\hline & Spec. 1102 & Spec. 1101 & Spec. 1101 \\
\hline Liquidus & $1300^{\circ} \mathrm{C}$ & $\mathbf{1 3 2 2}^{\circ} \mathrm{C}$ & $\mathbf{1 2 7 0}^{\circ} \mathrm{C}$ \\
\hline Phlogopite & - & - & $1270^{\circ} \mathrm{C}$ \\
\hline Diopside & $\mathbf{1 3 0 0}^{\circ} \mathrm{C}$ & $1322^{\circ} \mathrm{C}$ & $\mathbf{1 2 7 0}^{\circ} \mathrm{C}$ \\
\hline Leucite & - & $1293^{\circ} \mathrm{C}$ & $\mathbf{1 2 5 0}^{\circ} \mathrm{C}$ \\
\hline Solidus & - & $\sim 1000^{\circ} \mathrm{C}$ & $\sim 1040^{\circ} \mathrm{C}$ \\
\hline
\end{tabular}

Note: Rocks: 1101 - Massive holocrystalline wyomingite, Emmons Cone [Sobolev et al. 1975; Yagi, Matsumoto 1966]; 1102 - Porous, glassy orendite, Emmons Cone [Yagi, Matsumoto 1966].

According to the behavior of crystals, their growth or dissolution, it is possible to determine rather accurately both the liquidus temperature of melts of various rocks and the sequence of crystallizing phases. The degree of supercooling of the melt relative to the liquidus temperature could be inferred by the morphology and the content of defects in crystals. A plain-parallel specimen polished on both sides is prepared from the obtained sample for investigations.

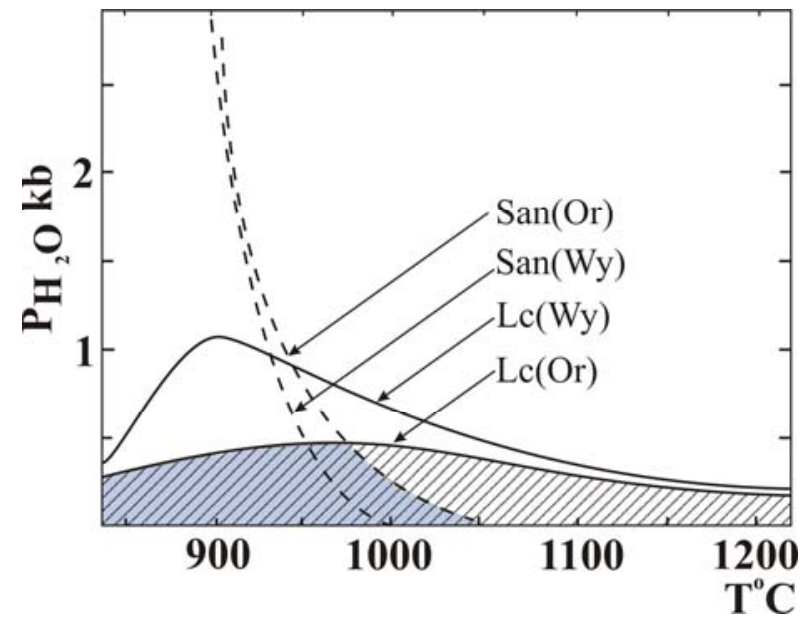

Fig. 3. The stability fields for leucite (solid curves) and sanidine (dashed curves) in wyomingitic (Wy) and orenditic melts (Or) (adopted from Barton, Hamilton 1978).

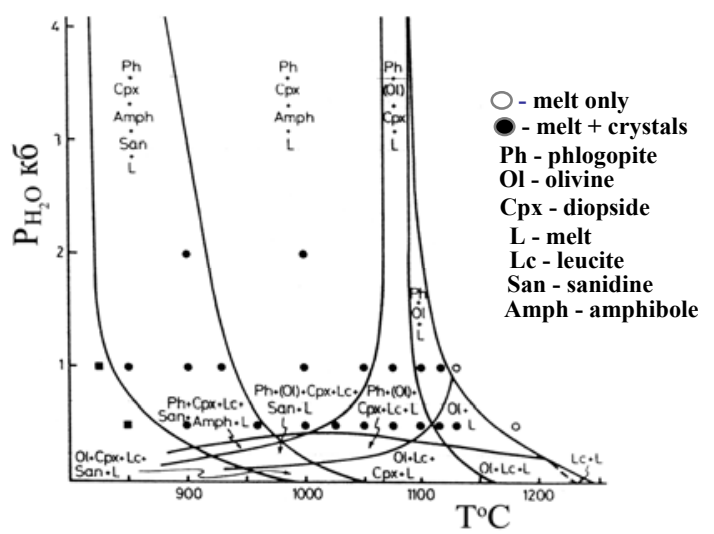

Fig. 4. The phase relationships of orenditic melts. LH $12\left(1,23 \% \mathrm{H}_{2} \mathrm{O}\right)$ (Barton, Hamilton 1978) 


\section{Results}

Applying the technique of sampling of silicate samples and their optical express analysis, we have:

a) determined the liquidus temperature of orendite melt at atmospheric pressure $\left(1300+10^{\circ} \mathrm{C}\right)$ and established that leucite is the first to crystallize, most of it crystallizes at $1250-1150^{\circ} \mathrm{C}$ At $1150+10^{\circ} \mathrm{C}$, clinopyroxene of diopside composition cocrystallizes with leucite;

b) elucidated the dependence of the leucite crystal habit on the degree of melt supercooling relative to the liquidus temperature On supercooling of $<10 \quad{ }^{\circ} \mathrm{C}$ transparent euhedral crystals (almost free of melt inclusions) are produced on supercooling of $30{ }^{\circ} \mathrm{C}$, the crystals have occasional inclusions and on supercooling of $-50{ }^{\circ} \mathrm{C}$, skeletal-dendritic crystals with abundant melt inclusions form;

c) estimated the possible mechanism of entrapment of melt inclusions during the skeletal growth of crystallizing leucite and its subsequent euhedral faceting The entrapment dynamics during the crystal growth has been traced. At the final stage, the faces of skeletal crystals heal, and melt inclusions are conserved in the growth sectors.

The comparison of our results with the previous experimental and melt inclusion data (Barton, Hamilton 1978, 1982, Carmichael 1967, Sobolev et al. 1975, Sharygin et al. 1991) (Table 2, 3; Fig. 3, 4), suggests that crystallization of the Zirkel Mesa lamproitic magma began at $1240-1270^{\circ} \mathrm{C}$ and $\mathrm{P}_{\mathrm{H} 2 \mathrm{O}}<$ $0,5 \mathrm{~kb}$. The absence of skeletal leucite crystals in the Zirkel Mesa orendites may indicate that the supercooling of lamproitic melt is less than $50^{\circ} \mathrm{C}$. The alternation of orendites and wyomingites in volcanic strata evidences fluctuations in the fluid regime (first of all, water content) of magma when it erupted.

This work is supported by the Russian Foundation for Basic Research (grants nos. 08-05-00270, 08-0500134, 08-05-00335, 08-05-00412).

\section{References}

Barton, M., Hamilton, D.L., 1978. Water-saturated melting relations to 5 kbar of three Leucite Hills lavas. Contribution to Mineralogy and Petrology, 66, 1, 4149.

Barton, M., Hamilton, D.L., 1982. Water undersaturated melting experiments bearing upon the origin of potassium-rich magmas. Mineralogical Magazine, 45, 267-278.

Carmichael, I.S.E., 1967. The mineralogy and petrology of the volcanic rocks from the Leucite Hills, Wyoming. Contribution to Mineralogy and Petrology, 15, 24-66.

Günter, W. D., Hoinkes, G., Ogden, P. \& Pajari, G. E., 1990. Origin of leucite-rich and sanidine-rich flow layers in the Leucite Hills Volcanic Field, Wyoming. Journal of Geophysical Research, 95, (B10), 15.911-15.928.
Petrushin, E. I., Bazarov, L. Sh., Gordeeva, V. I. \& Sharygin, V. V., 2003. A heating stage for petrologic studies of alkaline igneous rocks. Instruments and Experimental Techniques, 46, 2, 240-243 (in Russian).

Petrushin, E.I., et al., 2004. Effect of temperature regime on crystallization of leucite from orendite melt (from experimental data). Russian Geology and Geophysics (in Russian), 45, 10, 1208-1215.

Sobolev, V.S., Bazarova, T.Ju., Yagi, K., 1975. Crystallization Temperature of Wyomingite from Leucite Hills. Contribution to Mineralogy and Petrology, 49, 301-308.

Yagi, K., Matsumoto, H., 1966. Note on leucite-bearing rocks from Leucite Hills, Wyoming, USA. J. Fac. Sci. Hokkaido Univ., IV, 13, 301-312.

Sharygin, V.V., Bazarova, T.Yu., 1991. Melt evolution features during crystallization of wyomingite of Leucite Hills, USA. Russian Geology and Geophysics (in Russian), 32, 6, 51-57. 